\title{
Microstructure Evolution in ODS Alloys with a High-Volume Fraction of Nano Oxides
}

\author{
Jiří Svoboda ${ }^{1, *}$, Vít Horník ${ }^{1}$, Luděk Stratil ${ }^{1}{ }^{10}$, Hynek Hadraba ${ }^{1}$, Bohuslav Mašek ${ }^{2}$, \\ Omid Khalaj ${ }^{3}$ (D) and Hana Jirková ${ }^{3}$ (D) \\ 1 Institute of Physics of Materials, Academy of Science of the Czech Republic, 61662 Brno, Czech Republic; \\ hornik@ipm.cz (V.H.); stratil@ipm.cz (L.S.); hadraba@ipm.cz (H.H.) \\ 2 COMTES FHT, 33441 Dobřany, Czech Republic; bohuslav.masek@mb.tu-chemnitz.de \\ 3 Regional Technological Institute, University of West Bohemia, 30100 Plzeň, Czech Republic; \\ khalaj@rti.zcu.cz (O.K.); hstankov@rti.zcu.cz (H.J.) \\ * Correspondence: svobj@ipm.cz; Tel.: +420-532-290-407
}

Received: 20 November 2018; Accepted: 15 December 2018; Published: 19 December 2018

check for updates

\begin{abstract}
Existing oxide dispersion strengthened (ODS) alloys are, besides Ni-based superalloy single crystals, the most creep-resistant materials. The creep resistance of the ODS alloys may, moreover, be significantly improved thanks to increasing the volume fraction of the nano oxides by more than one order of magnitude so that the oxides play a decisive role in strengthening. The present experimental study deals with two systems of such a high-volume fraction of nano oxides, namely, the Fe-11Al-1O and Fe-17Cr-7Al- $4 \mathrm{Y}_{2} \mathrm{O}_{3}$ systems prepared by mechanical alloying and hot rolling leading to a rather stable fine-grained microstructure. This microstructure undergoes static recrystallization at high temperatures. The kinetics of static recrystallization and coarsening of nano oxides in recrystallized grains is determined for both systems. The difference in kinetics of coarsening of Al-based and Y-based oxides in the Fe- $11 \mathrm{Al}-1 \mathrm{O}$ and Fe- $17 \mathrm{Cr}-7 \mathrm{Al}-4 \mathrm{Y}_{2} \mathrm{O}_{3}$ systems is expressive and predetermines the Fe- $17 \mathrm{Cr}-7 \mathrm{Al}-4 \mathrm{Y}_{2} \mathrm{O}_{3}$ system or similar ones to become the new leading system among creep- and oxidation-resistant materials for applications up to $1200{ }^{\circ} \mathrm{C}$.
\end{abstract}

Keywords: oxides; precipitation; nanocomposite; recrystallization; creep; ODS alloys

\section{Introduction}

To meet growing demands on energy and economic efficiency, new creep- and oxidation-resistant structural materials are being intensively examined in the searched for a radical breakthrough. The existing leading metallic materials are represented by two classical groups: (i) Ni-based superalloy single crystals and (ii) oxide dispersion strengthened (ODS) coarse-grained ferritic alloys.

The excellent creep properties of Ni-based superalloy single crystals are due to their microstructure, which consists of ordered cube-shaped $\gamma^{\prime}$-precipitates of a volume fraction of about $70 \%$ separated by thin channels of disordered $\gamma$ matrix. The mechanisms of creep are summarized in the overview paper [1], showing that plastic deformation starts by dislocation slip in the $\gamma$-channels, which is very difficult in the $\gamma^{\prime}$-precipitates. Micromechanical unit cell models [2,3] account for all decisive creep mechanisms inclusive of microstructure evolution and fit well to experiments. The instability of the $\gamma^{\prime}$-precipitates due to directional coalescence and/or coarsening above $900{ }^{\circ} \mathrm{C}$ and enormous processing costs (higher generations also contain considerable amounts of expensive $\mathrm{Re}$ and $\mathrm{Ru}$ ) seem to be the greatest drawback of the superalloy single crystals.

ODS ferritic alloys are intended for fusion reactors and 4th generation fission reactors. Their matrix is strengthened by very fine dispersion of stable Y-based oxides typically of size 5-20 nm and volume fraction of $0.3 \%$. The current trend is the development of new ODS alloys with even lower volume 
fraction of even finer sizes of oxides. Then, however, one cannot expect the resistivity of oxides against coarsening at very high temperatures. ODS alloys are produced in two steps: nano-composite powder from the matrix of the respective chemical composition and $\mathrm{Y}_{2} \mathrm{O}_{3}$ is produced by mechanical alloying (MA), which is then hot consolidated in the second step. The recent commercially produced ODS alloys are represented by MA956 or MA957 [4], PM 2000 or PM 2010 [5], ODM alloys [6], 1DK or 1DS [7]. The non-commercially produced, experimental and advanced versions of ODS alloys are ODS Eurofer [8], 12YWT [9], 14YWT [10] and 9YWT [11]. New research on 14YWT [12] showed that mechanical properties of ODS alloys can significantly be improved via optimized processing consisting of a controlled thermo-mechanical treatment and in lowering content of $\mathrm{N}$ and $\mathrm{C}$ introduced during MA. Both steps led to a significant increase in fracture toughness attributed to improved cohesion of grain boundaries. However, processing of 14YWT is still extremely demanding [12].

The excellent creep properties of the ODS alloys are explained by an attractive interaction of dislocations with oxides modeled by Rösler and Arzt [13], who predicted a threshold stress for creep decreasing with coarsening of oxides. A more detailed discrete dislocation model treating the collective interaction of precipitates with dislocations during creep has been published very recently [14]. A model for coarsening in multicomponent systems [15] shows that coarsening kinetics is proportional to the product of the solubility and the diffusion coefficient of $\mathrm{O}$ in the matrix. The solubility of $\mathrm{O}$ is determined by the chemical stability of the oxide (yttria is reported as the chemically most stable oxide) and a significant resistance against coarsening was confirmed by Krautwasser et al. [16] for yttria particles. The creep properties of ODS alloys are thus limited by the existence of grain boundaries allowing diffusional creep and intergranular damage. That is why the creep properties of fine-grained ODS alloys are much worse than those of coarse-grained ones. Typical creep strength (1000 $\mathrm{h}$ to fracture) of the top ODS alloys is 180 (120) MPa at 800 (900) ${ }^{\circ} \mathrm{C}$ [17]. The existence of grain boundaries, low creep ductility, and high processing costs seem to be the greatest drawback of the ODS alloys. As creep strength of the ODS alloys decreases with increasing temperature much less than that of superalloy single crystals [17] (the volume content of strengthening $\gamma^{\prime}$-precipitates and, thus, also creep strength progressively decreases when approaching dissolution temperature of the $\gamma^{\prime}$-precipitates), ODS alloys are preferred for temperatures above $1000^{\circ} \mathrm{C}$.

Interaction of dislocations with a dispersion of precipitates is generally the most effective strengthening mechanism in creep-resistant structural materials and it is utilized both in Ni-based superalloys and ODS alloys. A spontaneous precipitation is conditioned by a sufficient supersaturation of the matrix by precipitate-forming elements. In steels, where the precipitate-forming element is $C$, its supersaturation is achieved by dissolution of a sufficient amount of $C$ in austenite, in which solubility of $C$ is high, and by cooling to transform austenite to ferrite or martensite, where solubility of $C$ is low. The kinetics of precipitation can be simulated very effectively for rather complex systems e.g., by software package MATCALC [18].

To provoke spontaneous precipitation of oxides, being chemically much more stable than carbides, the indicated method is, unfortunately, useless since oxygen exhibits only a very low solubility in ferrite, austenite and even in melt, and a low volume fraction of precipitated oxides cannot sufficiently strengthen the material. However, a high amount of $\mathrm{O}$ can be captured ("dissolved") in a heavily deformed matrix with a very high density of defects acting as traps [19] for O. This is just the case of mechanically alloyed powders, where, moreover, trapping of $\mathrm{O}$ stabilizes defects against recovery and, thus, an immense amount of $\mathrm{O}$ can be captured in the matrix. After severe reduction in density of defects due to dynamic recrystallization occurring during hot consolidation (see, e.g., the respective micromechanical model [20]), the matrix becomes strongly supersaturated by $\mathrm{O}$, which provides an enormous chemical driving force for precipitation of very fine oxides. A term "recrystallization induced precipitation" can be suggested for this phenomenon.

The most important prerequisites for a high long-term creep and oxidation resistance of metallic materials for very high temperatures up to $1200{ }^{\circ} \mathrm{C}$ are their coarse-grained or single crystalline microstructure, very high resistance of precipitates against coarsening, and formation of a compact and 
very stable oxide film on the surface. The formation of the stable oxide film is very effectively achieved by a sufficient content of $\mathrm{Al}$ in the alloy. This is fulfilled for both studied systems and this topic is out of scope of this paper. The goal of the paper is to show that the coarse-grained structure as well as stability of precipitates against coarsening are met quite well by the simplest Fe-11Al-1O system and even much better by a more sophisticated $\mathrm{Fe}-17 \mathrm{Cr}-7 \mathrm{Al}-4 \mathrm{Y}_{2} \mathrm{O}_{3}$ system. Both systems are prepared by MA and consolidation by hot rolling. The microstructure evolution of grains and precipitated oxides is examined in detail and quantitatively evaluated in this paper.

\section{Preparation of Specimens}

During MA the powder particles are heavily deformed and repeatedly cold welded and fractured. Powders, finely cut bulk materials or even pieces of brittle materials like $\mathrm{Cr}$ can be used as inputs, which allow an easy tuning of chemical composition. If necessary, some inputs, such as yttria powder, are degassed in a vacuum furnace to minimize bubble formation during annealing of the consolidated material. If there are no hard particles such as corundum in the input, MA leads to homogenization of the powder up to the atomic level and to multiplication of defects up to saturation. A self-made ball mill was used for MA. A vacuum-tight milling container with volume of $22 \mathrm{dm}^{3}$ and diameter of $400 \mathrm{~mm}$ made from a low alloy steel was filled with 100 bearing balls of diameter $40 \mathrm{~mm}(10 \mathrm{~kg})$. An amount of $1 \mathrm{~kg}$ of the powder was mechanically alloyed by rotation of the milling container at $70 \mathrm{rpm}$ along the horizontal axis. After a sufficiently long MA (14 days for Fe-11Al-1O system and 8 days Fe- $17 \mathrm{Cr}-7 \mathrm{Al}-4 \mathrm{Y}_{2} \mathrm{O}_{3}$ systems), the powder properties became saturated and the particles consisted of a homogeneous solid solution with a huge density of defects like dislocations and vacancies. The optimal time of MA was determined from five hot consolidated and recrystallized specimens for both systems. As criteria of optimization, the sufficiently homogeneous distribution of nano oxides in the bulk as well as minimum contamination of the product by carbon from the bearing balls was used. The solubility of both substitutional and interstitial components was, by several orders of magnitude, higher than the equilibrium component due to segregation (trapping) at dislocations of extremely high density. During MA, precipitate-forming interstitials like O can be dissolved in a required amount (up to 5 at. \%!) in the defect-rich matrix. This phenomenon has been analyzed and discussed in detail very recently [21], with the conclusion that such a high solubility of interstitials is conditioned by an extremely high dislocation density of the order of $1017 \mathrm{~m}^{-2}$. The key point is that chemically very stable but rather soft yttria may also completely dissolve during MA after a sufficient time.

The Fe-11Al-1O powder was prepared by MA from Fe and $\mathrm{Al}$ powders and a proper amount of $\mathrm{O}_{2}$ gas. It must be noted that MA has to be performed in two steps:

1. $\mathrm{MA}$ of $\mathrm{Fe}$ powder alone in $\mathrm{O}_{2}$ gas closed in the airtight milling container.

2. Addition of $\mathrm{Al}$ powder and continuation of MA after evacuation.

This two-step procedure prevents the formation of detrimental hart and stable coarse $\mathrm{Al}$ oxides formed by reaction of $\mathrm{O}_{2}$ with $\mathrm{Al}$ powder particles during the initial stage of MA.

The Fe- $17 \mathrm{Cr}-7 \mathrm{Al}-4 \mathrm{Y}_{2} \mathrm{O}_{3}$ powder was prepared by $\mathrm{MA}$ of $\mathrm{Fe}, \mathrm{Al}$ and yttria powders, and small pieces of $\mathrm{Cr}$ in the evacuated airtight milling container. After MA for a sufficient time, both powders were chemically homogeneous with $\mathrm{O}$ atoms trapped at multiple defects.

Mechanically alloyed powders were handled in a protective gas (carbon dioxide) to avoid oxidation of the powder surface. To perform the hot consolidation, the powders were compacted in a steel container by nocking without any pre-sintering, evacuated and sealed by welding. The green density ranged from $58 \%$ to $61 \%$. After preheating the rolling container made from the seamless low alloy steel tube $10 / 1 \mathrm{~mm}$ for $5 \mathrm{~min}$ at $850{ }^{\circ} \mathrm{C}$, the powders were consolidated by hot rolling of the container at $850^{\circ} \mathrm{C}$. The thickness of the container was reduced to $3 \mathrm{~mm}$ and to $2 \mathrm{~mm}$ in two steps by a sufficiently fast rolling (rolls of diameter $75 \mathrm{~mm}$ with $60 \mathrm{rpm}$ ) to provoke an intensive dynamic recrystallization leading to a very fine-grained microstructure of the consolidated material. Such hot 
consolidation conditions resemble the conditions for hot extrusion. The final width of the strip was $16 \mathrm{~mm}$ and the material was fully dense in the central part of the width at $6 \mathrm{~mm}$. Thus, no hot isostatic pressing needed to be applied to remove residual porosity. If a rolling temperature below $800{ }^{\circ} \mathrm{C}$ is used, some residual pores remain in the central part of the sheet. Moreover, the use of a rolling temperature above $900{ }^{\circ} \mathrm{C}$ does not lead to storage of a sufficient amount of energy in grain boundaries and dislocations, so that the static recrystallization is not completed. Thus, one can conclude that hot consolidation of the studied systems is very easy and effective.

\section{Initial Microstructure of the Specimens}

The initial and developed microstructures of the consolidated Fe- $11 \mathrm{Al}-1 \mathrm{O}$ and Fe-17Cr-7Al- $4 \mathrm{Y}_{2} \mathrm{O}_{3}$ are characterized by scanning electron microscopy (SEM), LYRA 3 XMU FEG/SEMxFIB, Tescan Brno, Czech republic. The average grain size is evaluated by an in-house software according to the ASTM E112-13 (year 2013) "Standard Test Methods for Determining Average Grain Size".

The initial microstructure of the specimens is depicted in Figure 1. In Figure 1a one can observe that the microstructure of the consolidated Fe- $11 \mathrm{Al}-1 \mathrm{O}$ consists of practically equiaxed grains of average grain size $80 \mathrm{~nm}$ stabilized by alumina nano precipitates formed during hot rolling and/or already during warming the rolling container with the powder before the rolling. The microstructure of the consolidated Fe- $17 \mathrm{Cr}-7 \mathrm{Al}-4 \mathrm{Y}_{2} \mathrm{O}_{3}$ shown in Figure $1 \mathrm{~b}$ also consists of practically equiaxed grains of mean size $120 \mathrm{~nm}$. One can expect that the Y-based nano oxides are of mean size below $5 \mathrm{~nm}$, which cannot be visualized by SEM, and they are still in their growth stage. Then one can speculate that, in contrast to Fe-17Cr-7Al- $4 \mathrm{Y}_{2} \mathrm{O}_{3}$, the finer-grain microstructure of $\mathrm{Fe}-11 \mathrm{Al}-1 \mathrm{O}$ is due to well-developed dispersion of nano oxides, which effectively pin the grain boundaries.

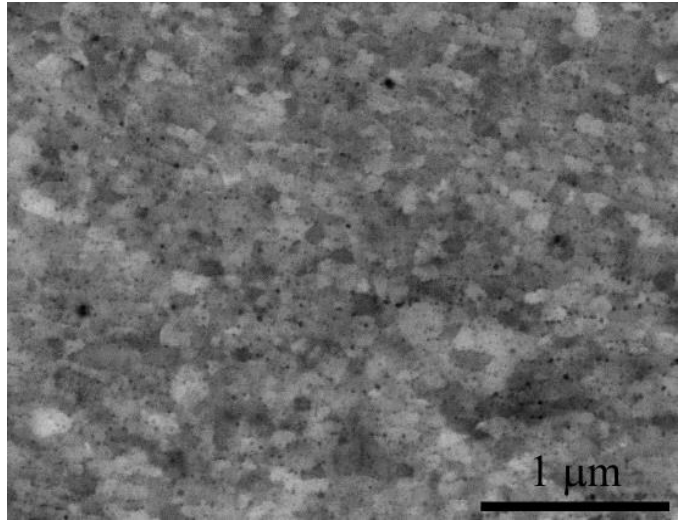

(a)

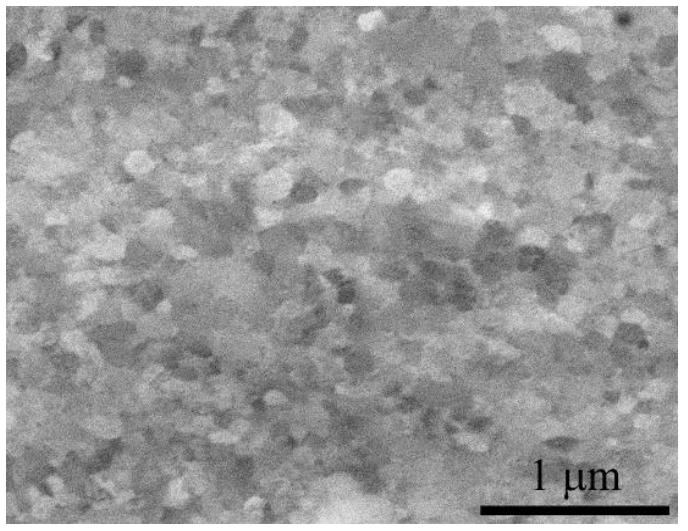

(b)

Figure 1. Microstructures of the consolidated (a) Fe-11Al-1O and (b) Fe-17Cr-7Al- $4 \mathrm{Y}_{2} \mathrm{O}_{3}$.

\section{Static Recrystallization in the Fe-11Al-1O System}

The grain microstructure development in a very similar system has been studied in detail [22], where the mechanism of the drastic increase (by more than two orders of magnitude) in grain size has been identified as static recrystallization driven by both the energy of stored dislocations and the grain boundary energy of very fine grains. The effect of pinning by oxides, which could provoke abnormal grain growth with similar effect, has been identified as a less important phenomenon. Moreover, the study in [22] has shown that the kinetics of the static recrystallization can be described by the Avrami equation.

The experimental observation of the present system confirms that only very few grains start growing during annealing at $1000{ }^{\circ} \mathrm{C}$ and they rather quickly consume practically all fine grains. A very small portion of slightly coarsened fine grains survive in the system more than $24 \mathrm{~h}$ and they are consumed by large grains later. Although the initial fine-grained microstructure seems to be rather isotropic, the statically recrystallized grains are elongated in both directions normal to the direction of 
rolling reduction. The examples of grain microstructures at different times of annealing are presented in Figure 2. The kinetics of growth of recrystallized grains in the direction of rolling reduction and in normal directions (both normal directions provide practically the same results), as well as the kinetics of fraction of recrystallized grains are presented in Figure 3.

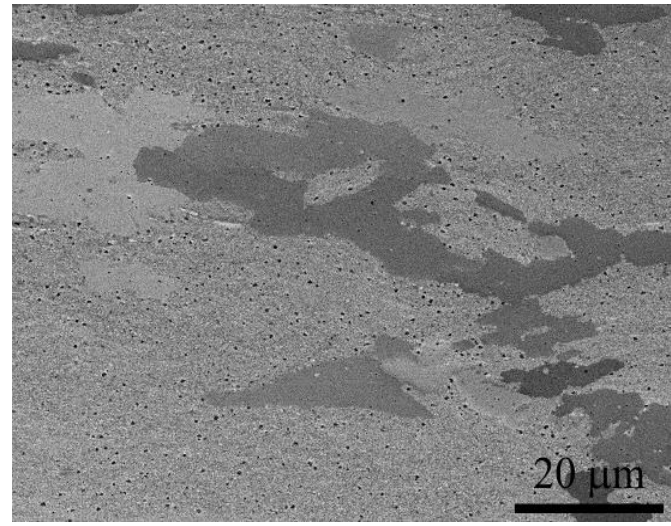

(a)

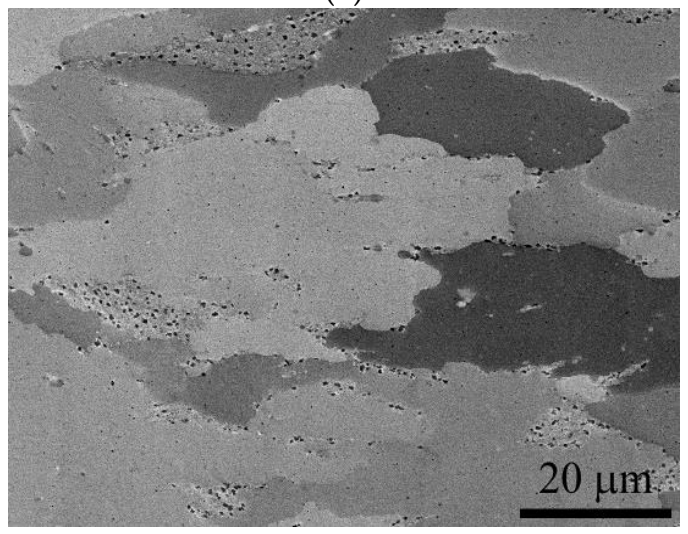

(c)

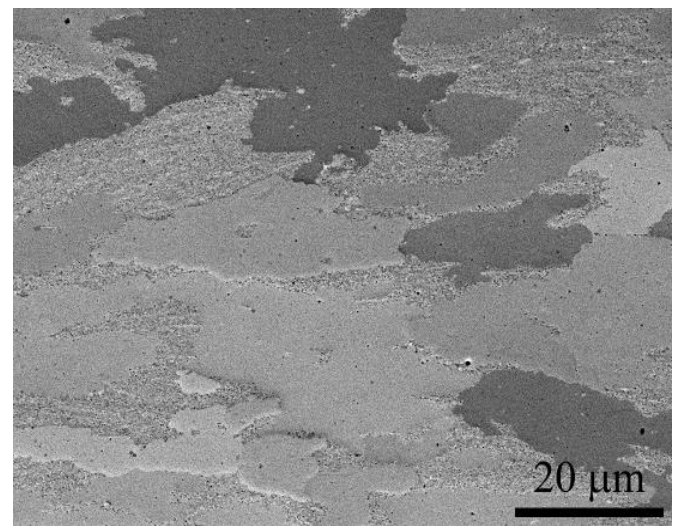

(b)

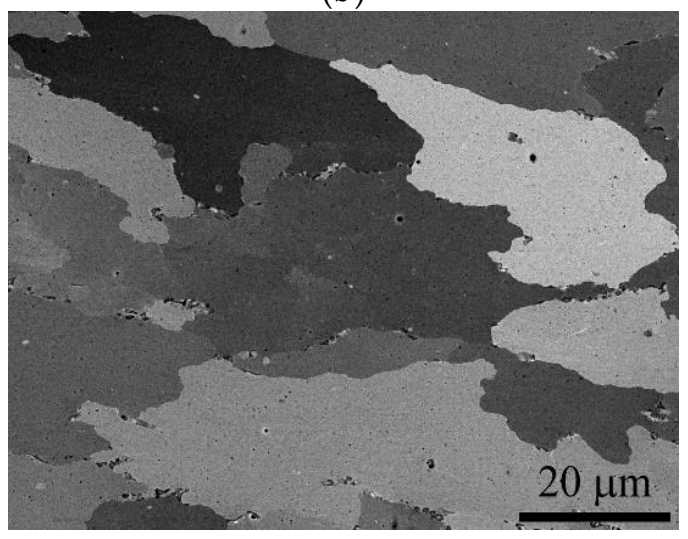

(d)

Figure 2. Scanning electron microscopy (SEM) micrographs demonstrating the evolution of the grain structure of the Fe-11Al-1O system after (a) $1 \mathrm{~h}$, (b) $2 \mathrm{~h},(\mathbf{c}) 4 \mathrm{~h}$ and (d) $24 \mathrm{~h}$ of annealing at $1000^{\circ} \mathrm{C}$.

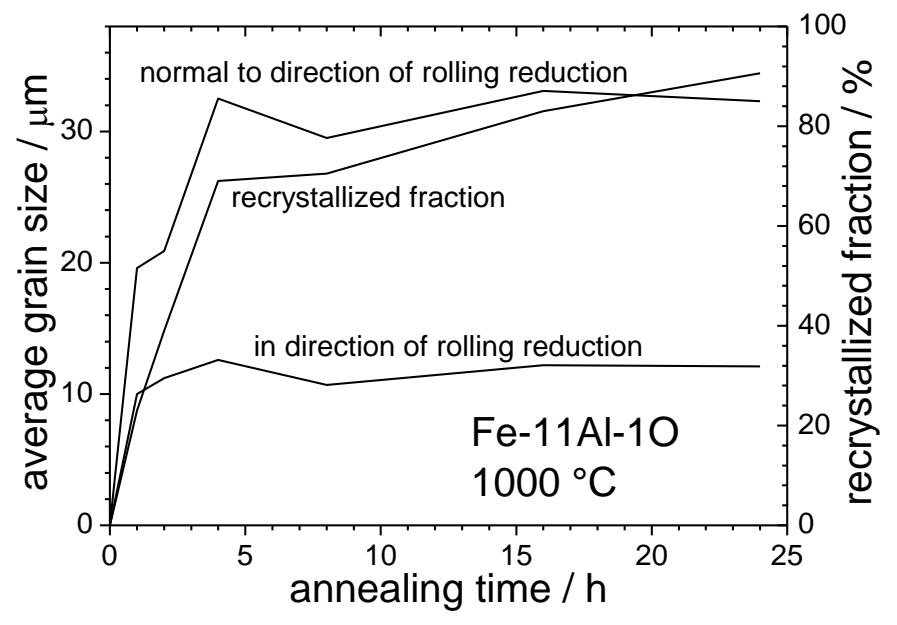

Figure 3. Evolution of the grain size normal and parallel to the rolling reduction and fraction of recrystallized area in the $\mathrm{Fe}-11 \mathrm{Al}-1 \mathrm{O}$ system during annealing at $1000{ }^{\circ} \mathrm{C}$. 


\section{Static Recrystallization in the Fe-11Al-10 System}

As the Fe-17Cr-7Al- $4 \mathrm{Y}_{2} \mathrm{O}_{3}$ system is much more stable against static recrystallization than the $\mathrm{Fe}-11 \mathrm{Al}-1 \mathrm{O}$ system, the annealing temperature is increased to $1120^{\circ} \mathrm{C}$ to obtain similar kinetics. All the features of the static recrystallization in the Fe- $17 \mathrm{Cr}-7 \mathrm{Al}-4 \mathrm{Y}_{2} \mathrm{O}_{3}$ system are the same as in the Fe-11Al-1O system. The examples of grain microstructures at different times of annealing are presented in Figure 4. The kinetics of growth of recrystallized grains in the direction of rolling reduction and in normal directions, as well as the kinetics of fraction of recrystallized grains are presented in Figure 5.

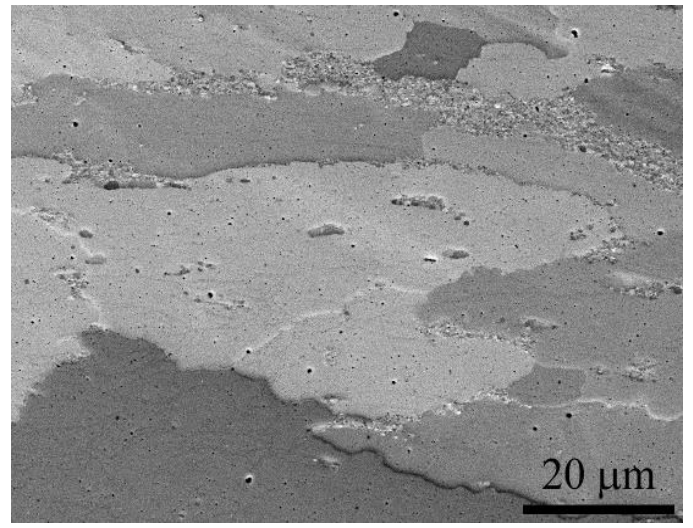

(c)

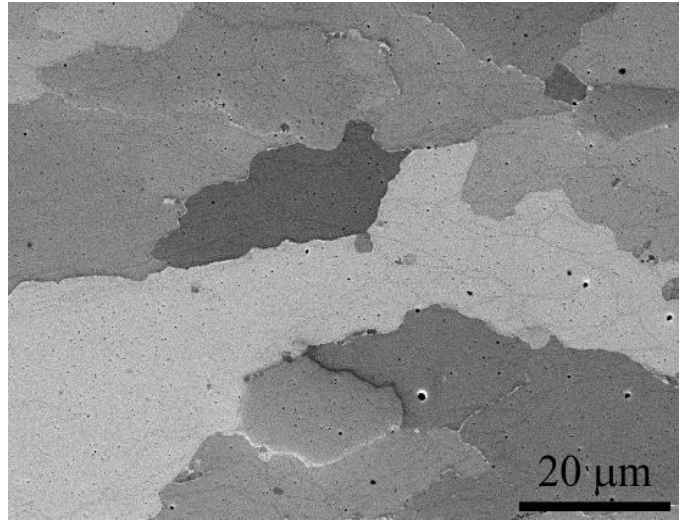

(d)

Figure 4. SEM micrographs demonstrating the evolution of the grain structure of the Fe- $17 \mathrm{Cr}-7 \mathrm{Al}-4 \mathrm{Y}_{2} \mathrm{O}_{3}$ system after (a) $1 \mathrm{~h},(\mathbf{b}) 2 \mathrm{~h},(\mathbf{c}) 4 \mathrm{~h},(\mathbf{d}) 24 \mathrm{~h}$ of annealing at $1120^{\circ} \mathrm{C}$.

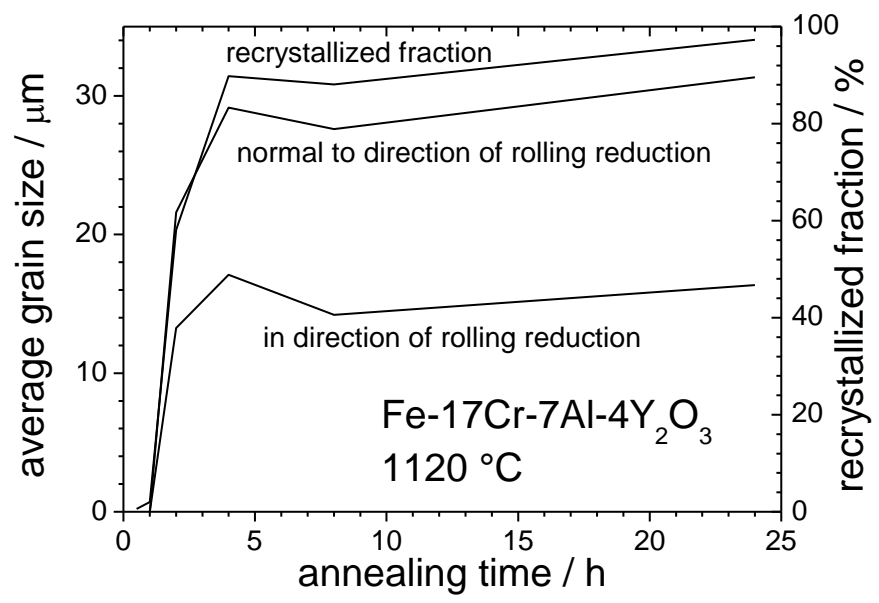

Figure 5. Evolution of the grain size normal and parallel to the rolling reduction and fraction of recrystallized area in the $\mathrm{Fe}-17 \mathrm{Cr}-7 \mathrm{Al}-4 \mathrm{Y}_{2} \mathrm{O}_{3}$ system during annealing at $1120{ }^{\circ} \mathrm{C}$.

\section{Coarsening of Oxides in the Fe-11Al-1O and Fe-17Cr-7Al-4 $\mathrm{Y}_{2} \mathrm{O}_{3}$ Systems}

To provoke a sufficiently fast coarsening of oxides, the annealing temperature is increased to $1200{ }^{\circ} \mathrm{C}$ for both systems. First of all, one could see that the static recrystallization is completed in both systems after $0.5 \mathrm{~h}$, see Figure 6 . Note that the grains are thinner in the direction of rolling contraction, but no systematic study has been performed to find the influence of processing parameters on the anisotropy of the grain structure. As, however, the results presented in this paper are obtained within a project aimed to develop new creep- and oxidation-resistant materials based on a large volume fraction of very stable nano oxides, one can expect that such a study will be carried out in the nearest future.

The examples of SEM micrographs of oxides dispersed in grain interiors after annealing for different times are shown in Figure 7 for the Fe-11Al-1O system and in Figure 8 for the Fe- $17 \mathrm{Cr}-7 \mathrm{Al}-4 \mathrm{Y}_{2} \mathrm{O}_{3}$ system. The kinetics of coarsening of oxides in both systems is compared in 
Figure 9. Note that during coarsening of oxides in the Fe-11Al-1O system, the shape of several large oxides changes from spheres to needles, and thus the cross-section area of the oxides is chosen for the representative characterization of the oxides in both systems. The fraction of the oxides with aspect ratio over 2.2 in the Fe-11Al-1O system increases from $20 \%$ after annealing for $24 \mathrm{~h}$ to $35 \%$ after annealing for $48 \mathrm{~h}$. Several models explain formation of needles. In the case of fixed volumetric misfit, the formation of needles is driven by the decrease of the total elastic strain energy [23]. However, at $1200{ }^{\circ} \mathrm{C}$ the volumetric misfit is most probably compensated by generation/annihilation of vacancies at the matrix/precipitate interface. Then, complex processes linked to anisotropy of interface energy and kinetic effects could explain formation of needles [24].

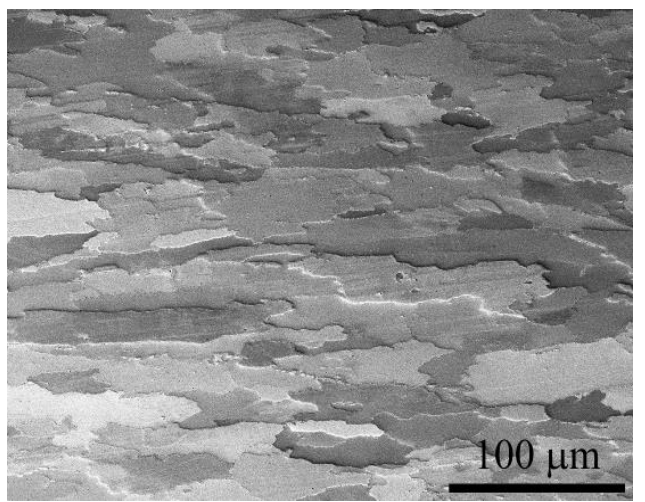

(a)

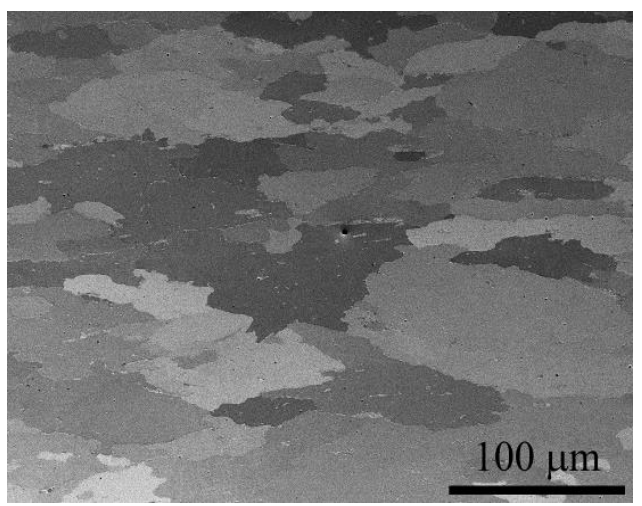

(b)

Figure 6. Completely recrystallized grain structure in (a) Fe- $11 \mathrm{Al}-1 \mathrm{O}$ and (b) $\mathrm{Fe}-17 \mathrm{Cr}-7 \mathrm{Al}-4 \mathrm{Y}_{2} \mathrm{O}_{3}$ systems after annealing at $1200^{\circ} \mathrm{C}$ for $0.5 \mathrm{~h}$.

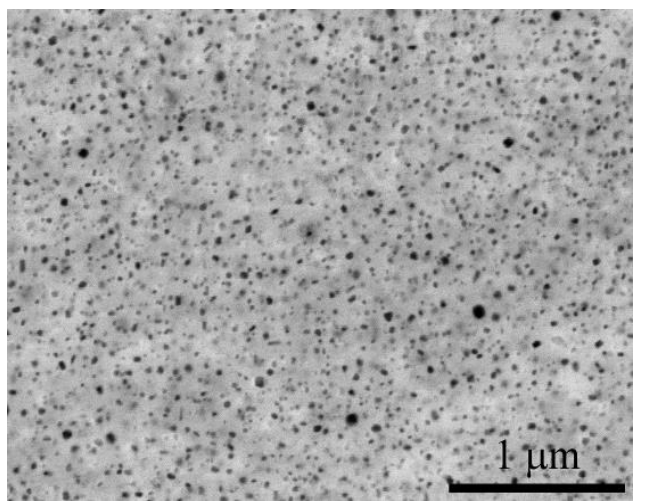

(a)

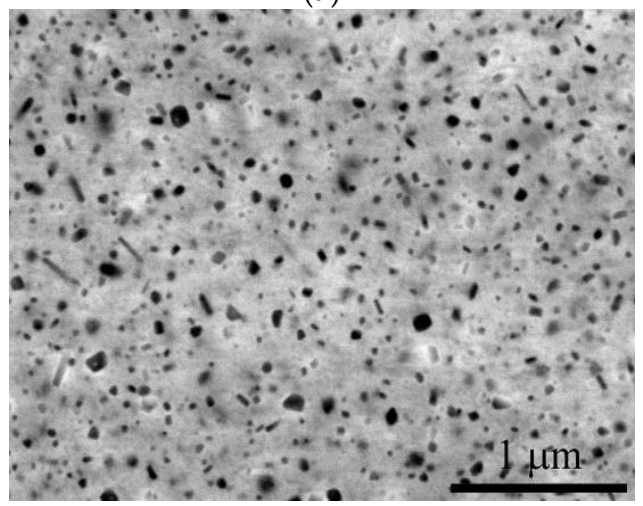

(c)

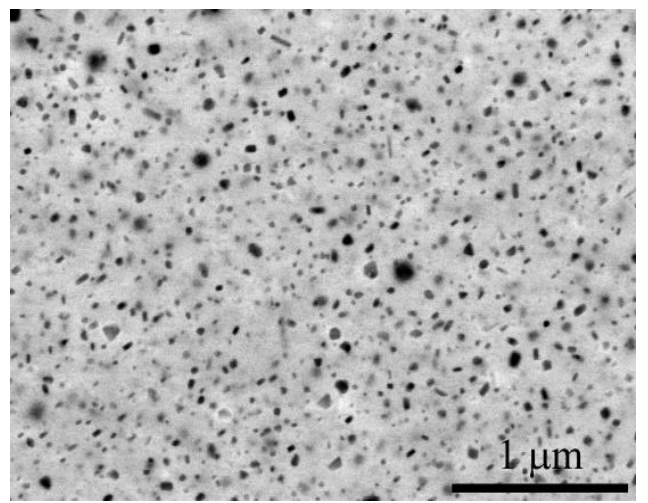

(b)

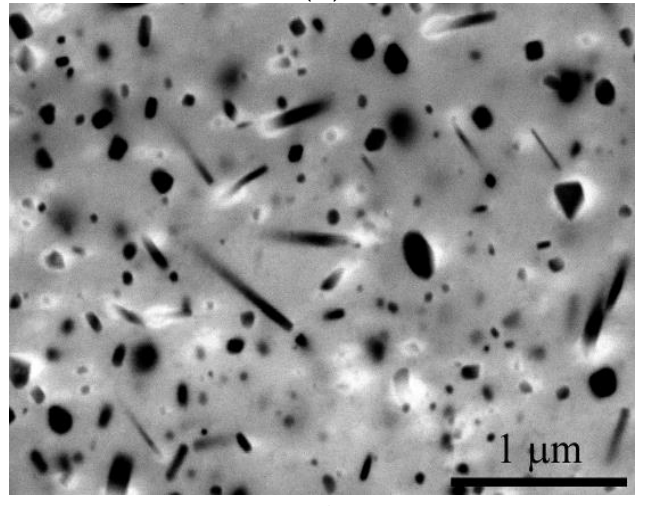

(d)

Figure 7. SEM micrographs of oxides dispersed in grain interiors after annealing at $1200{ }^{\circ} \mathrm{C}$ for (a) $1 \mathrm{~h}$, (b) $4 \mathrm{~h}$, (c) $8 \mathrm{~h}$, (d) $48 \mathrm{~h}$ in the Fe-11Al-1O system. 


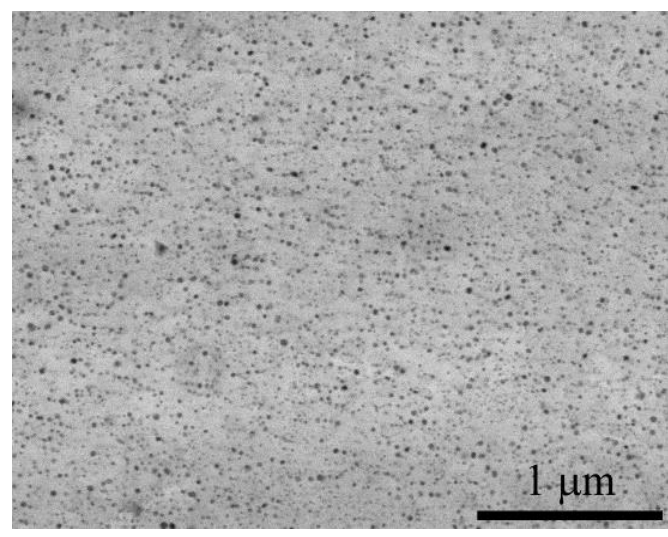

(a)

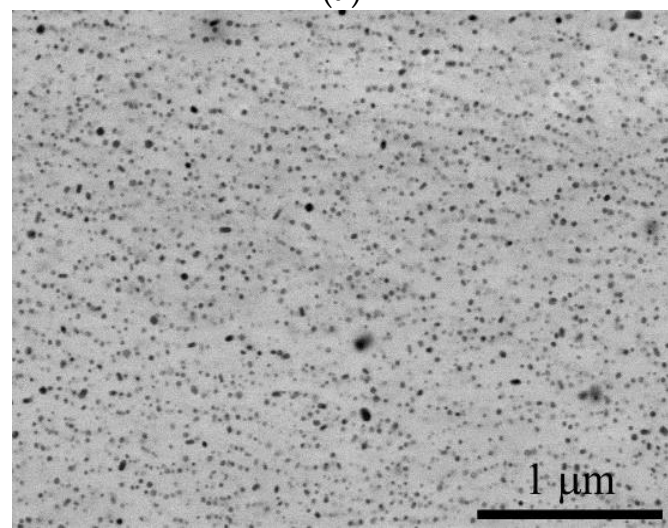

(c)

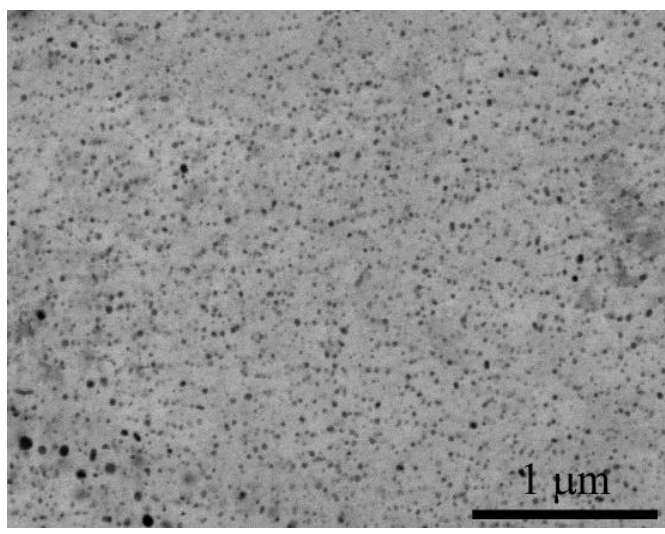

(b)

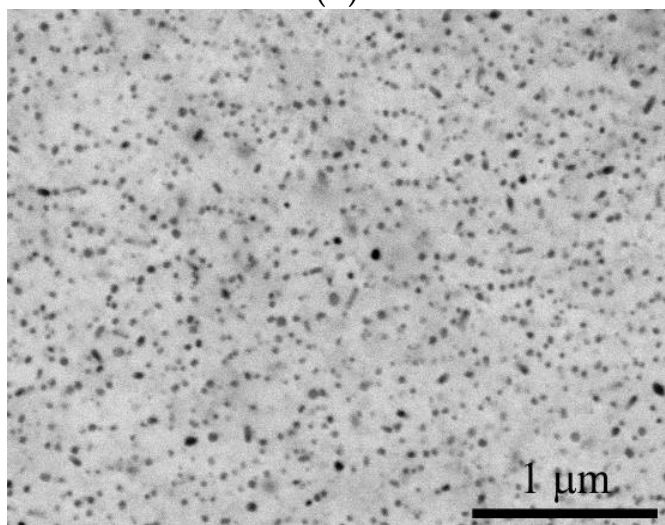

(d)

Figure 8. SEM micrographs of oxides dispersed in grain interiors after annealing at $1200{ }^{\circ} \mathrm{C}$ for (a) $1 \mathrm{~h}$, (b) $4 \mathrm{~h},\left(\right.$ c) $16 \mathrm{~h},(\mathrm{~d}) 72 \mathrm{~h}$ in the $\mathrm{Fe}-17 \mathrm{Cr}-7 \mathrm{Al}-4 \mathrm{Y}_{2} \mathrm{O}_{3}$ system.

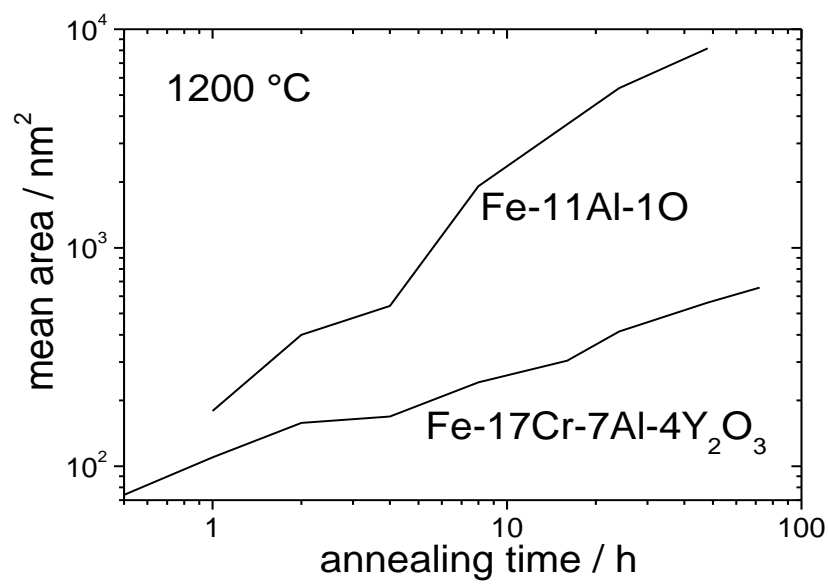

Figure 9. Evolution of mean oxide cross-section areas in both systems.

\section{Discussion}

Both systems with significantly different chemical composition (Fe-11Al-1O and Fe-17Cr-7Al-4Y ${ }_{2} \mathrm{O}_{3}$ ) are prepared by similar processing leading to nearly the same initial fine-grained microstructures. Although the evolution of the microstructure in both systems during subsequent annealing is qualitatively also similar, the quantitative difference due to their different chemical composition is substantial.

The first difference between both systems can be found in stability of the initial fine-grained microstructure. The kinetics of static recrystallization are practically the same at $1000{ }^{\circ} \mathrm{C}$ in the $\mathrm{Fe}-11 \mathrm{Al}-1 \mathrm{O}$ system and at $1120^{\circ} \mathrm{C}$ in the $\mathrm{Fe}-17 \mathrm{Cr}-7 \mathrm{Al}-4 \mathrm{Y}_{2} \mathrm{O}_{3}$ system (compare Figures 3 and 5). 
One can thus assume that the fine-grained microstructure of the Fe- $17 \mathrm{Cr}-7 \mathrm{Al}-4 \mathrm{Y}_{2} \mathrm{O}_{3}$ system exhibits a long-term stability at temperatures up to $1000{ }^{\circ} \mathrm{C}$ and keeps mechanical properties after rather severe thermal history.

The second much more important difference between both systems can be found in stability of oxides against coarsening after static recrystallization. The high stability of precipitates is one of the most important properties determining the long-term creep resistance. The difference in kinetics of precipitate coarsening in both systems is enormous at $1200^{\circ} \mathrm{C}$, see Figure 9. While the initial mean size of the oxides after static recrystallization is practically the same, the mean cross-section area (corresponds to squared size) of the oxides increases by a factor of 200 in the Fe-11Al-1O system and less than by a factor of $10 \mathrm{in}$ the Fe- $17 \mathrm{Cr}-7 \mathrm{Al}-4 \mathrm{Y}_{2} \mathrm{O}_{3}$ system after annealing for $100 \mathrm{~h}$. The extrapolation in time by using Figure 9 for the Fe- $17 \mathrm{Cr}-7 \mathrm{Al}-4 \mathrm{Y}_{2} \mathrm{O}_{3}$ system leads to mean size of oxides of $45 \mathrm{~nm}$ $(72 \mathrm{~nm})$ after $1000 \mathrm{~h}(10,000 \mathrm{~h})$ annealing at $1200^{\circ} \mathrm{C}$.

Note that the curves in Figure 9 have differently steepness. The steepness corresponding to the Fe- $11 \mathrm{Al}-1 \mathrm{O}$ system is approximately 1 , that corresponding to the $\mathrm{Fe}-17 \mathrm{Cr}-7 \mathrm{Al}-4 \mathrm{Y}_{2} \mathrm{O}_{3}$ system is about $1 / 2$ and that corresponding to the well-known Lifshitz, Slyozov and Wagner (LSW) theory is $2 / 3$. The reason for this rather significant disagreement could be in the initial size distribution of the precipitated oxides, due to evolution of the density of the matrix/oxide interface energy by processes in the interface and by its dependence on size of the oxides. In any case, the steepness of $1 / 2$ for the $\mathrm{Fe}-17 \mathrm{Cr}-7 \mathrm{Al}-4 \mathrm{Y}_{2} \mathrm{O}_{3}$ system is a good indication, though the reason for it is not clarified yet.

The nucleation and growth stages are usually separated from the coarsening (Ostwald ripening) stage by a retarding stage as described in [24]. The retarding stage starts with the saturation of the volume content of the precipitates. During this stage, the initially very narrow size distribution produced by nucleation and growth is gradually widened without decreasing the number of precipitates and approaches stationary LSW size distribution. According to [24], the onset of the Ostwald ripening stage (end of retarding stage) is indicated by the decrease of the number density of precipitates. As one can see in Figure 10, the number density already decreases in the initial stage of annealing at $1200{ }^{\circ} \mathrm{C}$ and, thus, we can conclude that the performed measurements really characterize the stage of the Ostwald ripening.

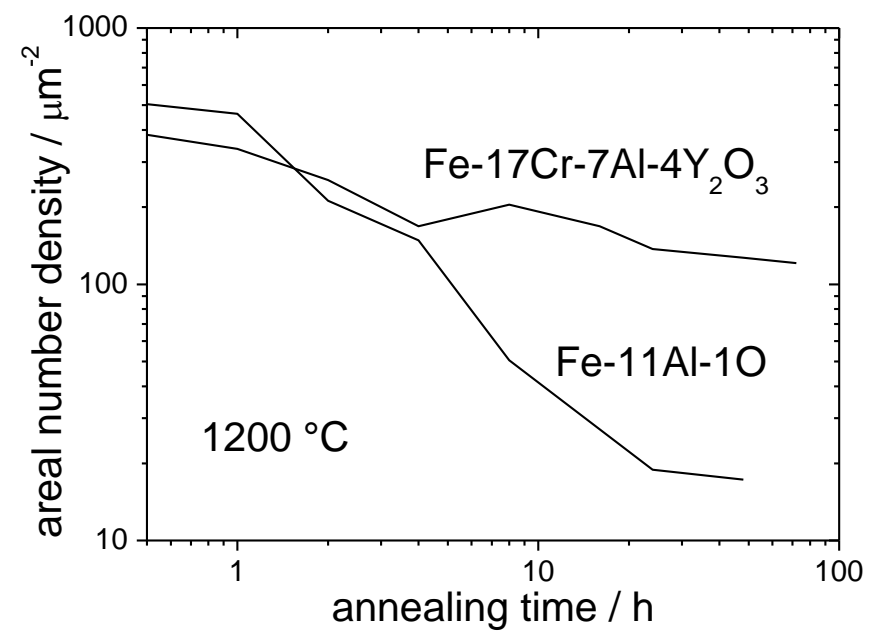

Figure 10. Evolution of areal number densities of oxides in both systems.

Although it seems that the Fe-11Al-1O system is very cheap due to low cost of inputs, and, thus, could find a large field of applications, in reality, the final Fe-11Al-1O material is more expensive than that of $\mathrm{Fe}-17 \mathrm{Cr}-7 \mathrm{Al}-4 \mathrm{Y}_{2} \mathrm{O}_{3}$. The reason is that the MA of the $\mathrm{Fe}-17 \mathrm{Cr}-7 \mathrm{Al}-4 \mathrm{Y}_{2} \mathrm{O}_{3}$ system is significantly more effective (MA takes only half the time) compared to the Fe-11Al-1O system. This effectivity significantly outweighs the lower costs of inputs of the Fe-11Al-1O system (the difference is about $\mathrm{USD} 3 / \mathrm{kg})$. 


\section{Conclusions}

Coarse-grained alloys strengthened by nano oxides of several percent of volume fraction are promising creep-resistant materials for very high temperatures thanks to high stability of oxides against coarsening.

Two systems, Fe- $11 \mathrm{Al}-1 \mathrm{O}$ and $\mathrm{Fe}-17 \mathrm{Cr}-7 \mathrm{Al}-4 \mathrm{Y}_{2} \mathrm{O}_{3}$, with nearly the same initial fine-grained microstructure, are examined with respect to the kinetics of static recrystallization and to the coarsening of nano oxides in recrystallized grains. The following conclusions can be drawn:

- Static recrystallization occurs in the Fe- $11 \mathrm{Al}-1 \mathrm{O}$ system at $1000{ }^{\circ} \mathrm{C}$ and in the $\mathrm{Fe}-17 \mathrm{Cr}-7 \mathrm{Al}-4 \mathrm{Y}_{2} \mathrm{O}_{3}$ system at $1120{ }^{\circ} \mathrm{C}$ with nearly the same kinetics leading to practically the same coarse-grained $(25 \mu \mathrm{m})$ microstructure with a dispersion of nano oxides of mean size $10 \mathrm{~nm}$ in grain interiors.

- Coarsening of oxides in the Fe- $11 \mathrm{Al}-1 \mathrm{O}$ system at $1200^{\circ} \mathrm{C}$ is about two orders of magnitude faster than in the Fe-17Cr-7Al- $4 \mathrm{Y}_{2} \mathrm{O}_{3}$ system.

- An admirable stability of the Y-based oxides and an excellent oxidation predetermine the Fe-17Cr-7Al- $4 \mathrm{Y}_{2} \mathrm{O}_{3}$ and similar systems to become oxidation- and creep-resistant structural materials.

Author Contributions: conceptualization, J.S. and H.J.; methodology, J.S., L.S., B.M., H.J.; preparation of materials, J.S.; heat treatment, L.S. and V.H.; preparation of metallographic sections H.H. and L.S.; electron microscopy, V.H., L.S. and H.H.; quantitative evaluation of micrographs, B.M., O.K. and H.J.; writing-original draft preparation, J.S., B.M. and H.J.; writing-review and editing, J.S., L.S., B.M., O.K. and H.J.

Funding: The financial support by the Czech Science Foundation in the frame of the Project 17-01641S is acknowledged. B.M. acknowledges financial support by the Ministry of Education, Youth and Sports in the frame of the Project LO1412 DEWEMAT.

Conflicts of Interest: The authors declare no conflict of interest.

\section{References}

1. Pollock, T.M.; Argon, A.S. Directional coarsening in nickel-base single crystals with high volume fractions of coherent precipitates. Acta Metall. Mater. 1994, 42, 1859-1874. [CrossRef]

2. Svoboda, J.; Lukáš, P. Model of creep in $\langle 001\rangle$-oriented superalloy single crystals. Acta Mater. 1998, 46, 3421-3431. [CrossRef]

3. Svoboda, J.; Lukáš, P. Creep deformation modelling of superalloy single crystals. Acta Mater. 2000, 48, 2519-2528. [CrossRef]

4. Material data sheet; Incoloy, alloy MA 956; Incoloy, alloy MA 957; Inco Alloys Limitted: Hereford, U.K.

5. Korb, G.; Rühle, M.; Martinz, H.-P. New iron based ODS-superalloys for high demanding applications. In Proceedings of the International Gas Turbine and Aeroengine Congress and Exposition, Orlando, FL, USA, 3-6 June 1991.

6. Kazimierzak, B.; Prignon, J.M.; Fromont, R.I. An ODS Material with outstanding creep and oxidation resistance above $1100{ }^{\circ} \mathrm{C}$. Mater. Des. 1992, 13, 67-70. [CrossRef]

7. Ukai, S.; Harada, M.; Okada, H.; Inoue, M.; Nomura, S.; Shikakura, S.; Nishida, T.; Fujiwara, M.; Asabe, K. Tube manufacturing and mechanical properties of oxide dispersion strengthened ferritic steel. J. Nucl. Mater. 1993, 204, 74-80. [CrossRef]

8. Schaeublin, R.; Leguey, T.; Spätig, P.; Baluc, N.; Victoria, M. Microstructure and mechanical properties of two ODS ferritic/martensitic steels. J. Nucl. Mater. 2002, 307-311, 778-782. [CrossRef]

9. Klueh, R.L.; Shingledecker, J.P.; Swindeman, R.W.; Hoelzer, D.T. Oxide dispersion-strengthened steels: A comparison of some commercial and experimental alloys. J. Nucl. Mater. 2005, 341, 103-114. [CrossRef]

10. Kim, J.H.; Byun, T.S.; Hoelzer, D.T.; Kim, S.-W.; Lee, B.H. Temperature dependence of strengthening mechanisms in the nanostructured ferritic alloy 14YWT: Part I-Mechanical and microstructural observations. Mater. Sci. Eng. A 2013, 559, 101-110. [CrossRef]

11. Byun, T.S.; Yoon, J.H.; Wee, S.H.; Hoelzer, D.T.; Maloy, S.A. Fracture behaviour of 9Cr nanostructured ferritic alloy with improved fracture toughness. J. Nucl. Mater. 2014, 449, 39-48. [CrossRef] 
12. Hoelzer, D.T.; Unocic, K.A.; Sokolov, M.A.; Byun, T.S. Influence of processing on the microstructure and mechanical properties of 14YWT. J. Nucl. Mater. 2016, 471, 251-265. [CrossRef]

13. Rösler, J.; Arzt, E. A new model based creep equation for dispersion strengthened materials. Acta Metall. 1990, 38, 671-683. [CrossRef]

14. Záležák, T.; Svoboda, J.; Dlouhý, A. High temperature dislocation processes in precipitation hardened crystals investigated by a 3D discrete dislocation dynamics. Int. J. Plast. 2017, 97, 1-23. [CrossRef]

15. Fischer, F.D.; Svoboda, J.; Fratzl, P. A Thermodynamical approach to grain growth and coarsening. Philos. Mag. 2003, 83, 1075-1093. [CrossRef]

16. Krautwasser, P.; Czyrska-Filemonowitz, A.; Widera, M.; Carsughi, F. Thermal stability of dispersoids in ferritic oxide strengthened alloys. Mater. Sci. Eng. A 1994, 177, 199-208. [CrossRef]

17. Steckmeyer, A.; Rodrigo, V.H.; Gentzbittel, J.M.; Rabeau, V.; Fournier, B. Tensile anisotropy and creep properties of a Fe-14CrWTi ODS ferritic steel. J. Nucl. Mater. 2012, 426, 182-188. [CrossRef]

18. The Scientific Tool Box. Available online: https://www.matcalc.at (accessed on 17 December 2018).

19. Svoboda, J.; Shan, Y.; Kozeschnik, E.; Fischer, F.D. Determination of depths of multiple traps for interstitials and their influence on diffusion kinetics. Model. Simul. Mater. Sci. Eng. 2014, 22, 065015. [CrossRef]

20. Riedel, H.; Svoboda, J. A model for strain hardening, recovery, recrystallization and grain growth with applications to forming processes of nickel base alloys. Mater. Sci. Eng. A 2016, 665, 175-183. [CrossRef]

21. Svoboda, J.; Ecker, W.; Razumovskiy, V.I.; Zickler, G.A.; Fischer, F.D. Kinetics of interaction of impurity interstitials with dislocations revisited. Prog. Mater. Sci. 2018, in press. [CrossRef]

22. Bártková, D.; Šmíd, M.; Mašek, B.; Svoboda, J.; Šiška, F. Kinetic study of static recrystallization in an Fe-Al-O ultra-fine-grained nanocomposite. Philos. Mag. Lett. 2017, 97, 379-385. [CrossRef]

23. Müller, R.; Gross, D. 3D simulation of equilibrium morphologies of precipitates. Comput. Mater. Sci. 1998, 11, 35-44. [CrossRef]

24. Svoboda, J.; Fischer, F.D.; Mayrhofer, P.H. A model for evolution of shape changing precipitates in multicomponent systems. Acta Mater. 2008, 56, 4896-4904. [CrossRef]

25. Perez, M.; Dumont, M.; Acevedo-Reyes, D. Implementation of classical nucleation and growth theories for precipitation. Acta Mater. 2008, 56, 2119-2132. [CrossRef]

(C) 2018 by the authors. Licensee MDPI, Basel, Switzerland. This article is an open access article distributed under the terms and conditions of the Creative Commons Attribution (CC BY) license (http://creativecommons.org/licenses/by/4.0/). 